\section{Microbiological and chemical analysis of land snails commercialised in Sicily}

\author{
Antonello Cicero, Giuseppe Giangrosso, \\ Gaetano Cammilleri, Andrea Macaluso, \\ Vittoria Currò, Lucia Galuppo, \\ Daniela Vargetto, Domenico Vicari, \\ Vincenzo Ferrantelli \\ Institute for Experimental Veterinary \\ Medicine of Sicily, Palermo
}

\begin{abstract}
In this study 160 samples of snails belonging to the species Helix aspersa maxima and Helix aspersa muller were examined for chemical and microbiological analysis. Samples came from Greece and Poland. Results showed mean concentration of cadmium $(0.35 \pm 0.036$ $\mathrm{mg} / \mathrm{kg})$ and lead $(0.05 \pm 0.013 \mathrm{mg} / \mathrm{kg})$ much higher than the limit of detection. Mercury levels in both species were not detected. Microbiological analysis revealed the absence of Salmonella spp. and Clostridium spp. in both examined species. $E$. coli and $K$. oxytoca were observed in Helix aspersa maxima and Helix aspersa muller. Furthermore, one case of fungi positivity in samples of Helix aspersa muller was found. The reported investigations highlight the need to create and adopt a reference legislation to protect the health of consumers.
\end{abstract}

\section{Introduction}

Terrestrial gastropods, commonly named chiocciole, constitute a niche food product, traditionally appreciated by Sicilian consumers. These products have a seasonally marketing, with a peak in the summer period (Tedde et al., 2009). Genus Helix (H. aspersa, H. pomatia, $H$. lucorum or Turkish snail) are the gastropods most commonly used for food production. They are usually considered as a minor food due to their low consumption. However, in some countries they are commonly consumed both in the breeding and capture forms (Sava, 2013).

Chiocciole production falls within the scope of EC Reg. n.852/04, while the transformation follows the EC Reg. n. 853/04 (European Commission, 2004a, 2004b). However, there is no legislation that lays down specific requirements for microbiological and chemistry of these products. Bivalve are the only molluscs class subjected to regulations (EC Reg. 1881/06; European Commission, 2006). These regulations defines maximum levels of contaminants, including heavy metals, for foodstuffs, necessary insertion due to their accumulation ability. Numerous studies have been carried out using various species of terrestrial gastropods as bioindicators of environmental status (Regoli et al., 2006). In consideration of the risk posed by the possible presence of potentially pathogenic micro-organisms in gastronomic preparations, which does not include cooking priority to consumption (Marongiu et al., 1993), and in the absence of data relating to the possible contamination by heavy metals, it was deemed appropriate to gather information about microbiological and chemical properties of chiocciole samples commercialised in Sicily. Chiocciole can be considered as a pollutant vector due to their behaviour, as they live on soil and feed on plants with high heavy metals concentration (Scaffardi et al., 2007). Furthermore, microbiological aspects seem to be very important for the hygienic aspects assessment because these snails are possible carriers of many parasitic and bacterial forms. In fact, predominant bacterial species such as Enterobacteriaceae (Citrobacter, Morganella, Klebsiella ed Enterobacter, E. coli, Pseudomonadaceae, Proteus spp., Hafnia, Yersinia enterocolitica), gram-positive Staphylococcus (S. aureus) and Listeria in the shell were detected. Frequently, the presence of fungi such as Aspergillus spp., Chrysosporium spp., Fusarium spp., Rhizopus spp. and Mucor spp. and parasites such as Clonorchis sinensis and Fasciola can be detected as well. Aeromonas hydrophila, Escherichia coli e Listeria monocytogenes are among the food-borne diseases agents that can be revealed (Cantoni, 2013). Stored methods such as freezing cannot be considered as a prevention mean for Enterobacter cloacae, Klebsiella oxytoca, Pseudomonas aeruginosa, Aeromonas hydrophila, Staphylococcus spp., Listeria monocytogenes, Bacillus subtilis and $B$. cereus. Microbiological risk is linked to the consumption of treated products (ready to eat) contaminated by Listeria monocytogenes and enterotoxic strain of Staphylococcus aureus and Bacillus cereus (Wallace et al., 1975).

The aim of this study was to assess the presence of microbiological and chemical contaminations in gastropods samples from Poland (Helix aspersa maxima) and Greece (Helix aspersa muller).

\section{Materials and Methods}

Of each species of gastropods, 80 samples were examined by the Veterinary Institute of Sicily laboratories in February 2014. The Chemistry and Food Technologies Area was responsible for the determination of heavy
Correspondence: Vincenzo Ferrantelli, Institute for Experimental Veterinary Medicine of Sicily, via Gino Marinuzzi 3, 90129 Palermo, Italy.

Tel. +39.091.656.5111.

E-mail: vincenzo.ferrantelli@izssicilia.it

Key words: Snails; Heavy metals; Food microbiology.

Received for publication: 29 May 2014.

Revision received: 2 October 2014

Accepted for publication: 3 October 2014.

This work is licensed under a Creative Commons Attribution 3.0 License (by-nc 3.0).

(C) Copyright A. Cicero et al., 2015

Licensee PAGEPress, Italy

Italian Journal of Food Safety 2015; 3:4196

doi:10.4081/ijfs.2015.4196

metals [cadmium $(\mathrm{Cd})$, lead $(\mathrm{Pb})$ and mercury (Hg)], while the Territorial Health Department was responsible of microbiological analysis. The validated methodology on heavy metals contamination in fish products has been retained the most analogous for the implementation of our analysis. The determination of heavy metals was performed by an inductively coupled plasma mass spectrometry (ICP-MS) (Agilent 7700 series; Agilent Technologies, Santa Clara, CA, USA), an ICP plasma torch analyser producing ionisation and a mass spectrometer for the ion separation and detection. Extraction of samples $(\approx 1 \mathrm{~g}$ for each one) was performed. Subsequently the extract was placed in a polytetrafluoroethylene (PTFE) microwave vessel with $2 \mathrm{~mL}$ of $\mathrm{HNO}_{3}$ (65\% ultrapur) and $5 \mathrm{~mL}$ of $\mathrm{H}_{2} \mathrm{O}$ for mineralisation. Vessels containing the samples were closed and placed in Multiwave digestion 3000 (Anton Paar) digestor. After mineralisation the content was transferred into $50 \mathrm{~mL}$ PVC test tubes. Vessels were washed twice with $10 \mathrm{~mL}$ of ultrapure water, subsequently the content was transferred in $50 \mathrm{~mL}$ test tubes and diluted with ultrapure water for the ICPMS detection. This method can reveal $\mathrm{Cd}, \mathrm{Hg}$ and $\mathrm{Pb}$ concentration in $\mathrm{mg} / \mathrm{kg}$ (ppm). Microbiological analysis was performed for the research of Salmonella spp., Clostridium (in particular C. perfringens), E. coli, Yersinia, Listeria, Pseudomonas, Streptococcus, Klebsiella and fungi. Salmonella spp. research has provided a pre-enrichment phase in buffered peptone water, an enrichment phase in selective broth, an isolation phase on selective media (XLD e BGA) and biochemicals and serological tests. Clostridium perfringens research was performed by a Blood Agar and anaerobic incubation. For $E$. coli, Pseudomonas spp. and Klebsiella spp. detection a McConkey agar was utilised; blood Agar 
for Streptococcus spp.; enrichment broth and selective agar incubated at 25 and $30^{\circ} \mathrm{C}$ was utilised for Yersinia spp. and Listeria spp. determination. Fungi detection was performed with Agar Sabouraud. Isolates underwent catalase and oxydase tests, Gram coloration, Macromethods (KIA, TSI, Citrate, Ureasi test, Mobility test and Indole test) and Micromethods (API Kit) biochemical tests.

\section{Results}

Series analyses with gastropods matrices were conducted for validation testing of utilised method. Obtained results reported statistically equal dataset $(\mathrm{P}<0.01)$ to fish products assessment on repeatability values, mean recovery and robustness of the method. Limits of detection (LOD) were calculated according to the modality described on standard operating procedure (SOP) 18 and 36 for validation parameter calculation. Examined Helix aspersa maxima samples revealed a mean concentration of Cd equal to $0.35 \pm 0.036 \mathrm{mg} / \mathrm{kg}$. This concentration is considerably higher than the LOD of the method. $\mathrm{Pb}$ analysis showed a mean concentration of $0.05 \pm 0.013 \mathrm{mg} / \mathrm{kg}$. $\mathrm{Hg}$ levels in both species were under the LOD $(0.06$ $\mathrm{mg} / \mathrm{kg}$ ). Helix aspersa muller samples did not reveal a considerable heavy metals levels (Table 1).

Micorbiological results (Table 2) confirm bibliography data (Adegoke et al., 2011; Cirlan et al., 2010; Iovino et al., 2002; Kirkan et al., 2006; Marongiu et al., 1993; Temelli et al., 2006). Helix aspersa maxima samples revealed a good hygienic condition. In particular, samples were negative to the most tested microbes except 4 that were positive to $E$. coli, 3 to Pseudomonas luteola and 1 to Klebsiella oxitoca. Helix aspersa muller samples detected 2 positive subjects to Listeria innocua, 1 to fungi and 1 to Streptococcus.

\section{Discussion}

Obtained results on Helix aspersa maxima samples revealed a $\mathrm{Cd}$ concentration that cannot be negligible because data are significantly higher than the LOD of the method. These values can be traced to materials for agriculture such as sewage sludge containing high values of $\mathrm{Cd}$ that settle in the soil. Terrestrial gastropods living in the soil and vegetation act as bioaccumulator of these substances, thus becoming vectors through their consumption.

Daily uptake of $\mathrm{Cd}$ from food and beverages, in the absence of pollution, has been estimat-
Table 1. Avarage concentration values of heavy metals.

\begin{tabular}{lccc} 
& $\mathrm{Cd}(\mathrm{mg} / \mathrm{kg})$ & $\mathrm{Pb}(\mathrm{mg} / \mathrm{kg})$ & $\mathrm{Hg}(\mathrm{mg} / \mathrm{kg})$ \\
Helix aspersa maxima & $0.35 \pm 0.036$ & $0.05 \pm 0.013$ & $<\mathrm{LOD}$ \\
Helix aspersa muller & $<\mathrm{LOD}$ & $<\mathrm{LOD}$ & $<\mathrm{LOD}$ \\
\hline
\end{tabular}

$\mathrm{Cd}$, cadmium; $\mathrm{Pb}$, lead; $\mathrm{Hg}$, mercury; LOD, limit of detection.

Table 2. Dataset of microbiological analysis.

\begin{tabular}{|c|c|c|c|c|}
\hline Microorganisms & $\begin{array}{c}\text { Helix aspersa } \\
\text { muller }\end{array}$ & Positive (n) & $\begin{array}{l}\text { Helix aspersa } \\
\text { maxima }\end{array}$ & Positive (n) \\
\hline Salmonella spp. & - & 0 & - & 0 \\
\hline Clostridium spp. & - & 0 & - & 0 \\
\hline Escherichia coli & + & 12 & + & 4 \\
\hline Pseudomonas spp. & - & 0 & $+($ P. luteola $)$ & 3 \\
\hline Klebsiella spp. & $+($ K. oxytoca $)$ & 2 & $+($ K. oxytoca $)$ & 1 \\
\hline Streptococcus spp. & $+(\mathrm{S} . \beta$ emolitico $)$ & 1 & - & 0 \\
\hline Yersinia spp. & - & 0 & - & 0 \\
\hline Listeria spp. & + (L. innocua) & 2 & 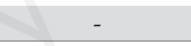 & 0 \\
\hline Fungi & + & 1 & 8 & 0 \\
\hline
\end{tabular}

ed in the UK to be between $10-30 \mu \mathrm{g}$ in a $70 \mathrm{~kg}$ man (Reilly, 1980; EFSA, 2009). The ingestion of Cd causes symptoms such as nausea, vomiting, abdominal cramp and headache within minute of ingestion. Long-term ingestion of $\mathrm{Cd}$ results in serious disease of the kidneys. A recent FA0 report established a weekly tolerable dose of cadmium equal to $400-500 \mathrm{mg}$. This would result in an average concentration in food of 0.04-0.05 mg/kg (EFSA, 2009). A recent EFSA report (2009) recognised a weekly tolerable dose equal to $25 \mathrm{~g} / \mathrm{kg}$. Consumption of contaminated foods is one of the most uptake ways for $\mathrm{Hg}$ exposition. High levels of $\mathrm{Pb}$ results in seious toxic effects in humans. Acute $\mathrm{Pb}$ poisoning manifests gastro-intestinal symptoms with dyspepsia, constipation with severe abdominal pain.

These results revealed terrestrial gastropods as heavy metal contamination vehicles for men, (in particular $\mathrm{Cd}$ and $\mathrm{Pb}$ detected in concentrations higher than LOD), although the EC Reg. 1881/2006 give higher limit values regarding marine molluscs. Microbiological aspects, considering that microbial flora is different between an epifragmata (pathogens free) and corritrice snail (that even dwells pathogenic saprophytic bacteria), declared a normative lack about the microbiological aspects. This notwithstanding, EC Reg. 2073/2005 establishes the limits for alive gastropods can be used as a valid mean for the consumer protection (Andrews et al., 1975). The presence of microorganisms in foods can be due to food elaboration and treatment. The risk for consumers increases with the consumption of non-termically treated foods.

\section{Conclusions}

A lack of legislative regulation suggests the need of control measures to protect the consumption of this product which is becoming increasingly popular and widespread in the food market. Hence, food business operators must pay attention throughout the production chain and distribution in order to avoid contamination by environmental and human origin bacteria. In general, a good control of spinneret coupled with a particular attention to raw materials quality and manufacturing practices respect, can be good prevention tools for foodborne desease prevention.

\section{References}

Adegoke AA, Bukola A-TC, Comfort IU, Olayinka AA, Amos KO, 2011. Snails as a meat source: epidemiological and nutritional perspectives. J Microb Antimicrob 2:1-5.

Andrews WH, Wilson CR, Romero A, Poelma PL, 1975. The Moroccan food snail, Helix aspersa, as a source of Salmonella. Appl Microbiol 29:328-30.

Cantoni, 2013. Available from: profcarlocantoni.blogspot.com/2013_07_01_archive.html

Cirlan AF, Floristean V, Sindilar E, 2010. The characterization of some microorganisms isolated from the meat of the food snail Helix pomatia. U Politeh Buch Ser A 56:348. 
EFSA, 2009. Cadmium in food: scientific opinion of the panel on contaminants in the food chain. Available from: http://www.efsa.europa.eu/it/efsajournal/p ub/980.htm

European Commission, 2004a. Regulation of the European Parliament and of the Council of 29 April 2004 on the hygiene of foodstuffs, 852/2004/EC. In: Official Journal, L 139/1, 30/04/04.

European Commission, 2004b. Regulation of the European Parliament and of the Council of 29 April 2004 laying down specific hygiene rules on the hygiene of foodstuffs, 853/2004/EC. In: Official Journal, L 139/55, 30/04/04.

European Commission, 2005. Commission Regulation of 15 November 2005 on microbiological criteria for foodstuffs, 2073/2005/EC. In: Official Journal, L 338/1, $22 / 12 / 05$

European Commission, 2006. Commission Regulation of 19 December 2006 setting maximum levels for certain contaminants in foodstuffs, 1881/2006/EC. In: Official Journal, L 364/5, 20/12/06.

Iovino F, Ferrantelli V, Cardamone C, Oliveri G, Di Noto AM, Cantoni C, 2002. Il controllo di lumache vive terrestri d'importazione: aspetti normativi ed esiti del controllo di laboratorio. Ing Alim 6:22-7.

Kirkan S, Goksov E0, Kaya 0, 2006. Detection of Listeria monocytogenes by using PCR in Helix pomatia. Turk J Vet Anim Sci 30:37580.

Marongiu E, Virgilio S, Sias S, Santoru F, 1993. Aspetti igienico sanitari di chiocciole utilizzate a scopo alimentare in Sardegna. Proc. 47th SISVet Congress, Riccione, Italy, 47:679-81.

Regoli F, Gorbi S, Fattorini D, Tedesco S, Notti A, Machella N, Bocchetti R, Benedetti M, Piva F, 2006. Use of the land snail Helix aspersa as sentinel organism for monitoring ecotoxicologic effects of urban pollution: an integrated approach. Environ Health Persp 114:63-9.

Reilly C, 1980. Metal contamination of food.
Elsevier Publ., Amsterdam, The Netherlands.

Sava C, 2013. Indagini sull'inquinamento da metalli pesanti "usuali" e "inusuali" nelle chiocciole per uso alimentare umano. Degree Diss., University of Padua ed., Italy. Available from: tesi.cab.unipd.it/43592/1/Sava_Clara.pdf

Scaffardi E, Ru G, Giordana G, 2007. Accumulo di metalli pesanti in chiocciole della specie Helix pomatia L. (Pulmonata, Helicidae) destinate al consumo umano. Il Chirone 1:8-11.

Tedde T, Virgilio S, Chessa G, Fiori G, Terrosu G, Rosa MN, Pinna C, Piras G. Rilievi microbiologici e chimici in gasteropodi terrestri commercializzati nella regione Sardegna. Available from: www.pagepressjournals.org/index.php/ijfs/article/view/ijf s.2009.5.23

Temelli S, Dokuzl C, Sen MKC, 2006. Determintion of microbiological contamination sources during frozen snails meat processing stages. Food Control 17:22-9. 